Jarostaw Horowski*

Toruń

\title{
Liberal education w ujęciu Jacques'a Maritaina
}

Badania, których efektem jest niniejszy artykuł, odnoszą się do pytania, jaki kształt powinna przyjąć edukacja liberalna, aby realizowała wpisany w nią cel, czyli budowanie wolności jednostki w kontekście wywieranych na nią we współczesnej rzeczywistości społeczno-kulturowej wpływów. Ich przedmiotem było stanowisko Jacques'a Maritaina w kwestii liberal education. Francuski filozof wypowiedział się na ten temat zwłaszcza w książce Education at the crossroads ${ }^{1}$, w której wyraził obawę, że współczesna edukacja - zamiast czynić człowieka bardziej człowiekiem - może prowadzić do podporządkowania go technokratycznemu społeczeństwu. Nie kwestionował przy tym wartości kształcenia technicznego, uznając je za konieczne, ale wyrażał niepokój brakiem zrozumienia sensu technologii w ludzkim życiu, czynieniem z niej zasady ludzkiego życia oraz zapoznaniem konieczności poszukiwania poprzez edukację nie tyle wiedzy, ile mądrości²

* Dr Jarosław Horowski jest adiunktem w Katedrze Filozofii Wychowania na Wydziale Nauk Pedagogicznych Uniwersytetu Mikołaja Kopernika w Toruniu.

1 Zob. J. Maritain, Education at the crossroads, New Haven and London 1972. W Polsce nie opublikowano dotąd tłumaczenia całego dzieła. Ukazały się jednak jego fragmenty: tenże, Od filozofii człowieka do filozofii wychowania, w: F. Adamski (red.), Człowiek - wychowanie - kultura. Wybór tekstów, Kraków 1993, s. 61-79 (pierwszy rozdział zatytułowany Cele wychowania), oraz tenże, Dynamika wychowania, „Znak” 9 (1991), s. 28-39 (fragmenty drugiego rozdziału).

${ }^{2}$ Por. tenże, Education, s. 113; tenże, Od filozofii, s. 68-69, 72-73; tenże, Moralne i duchowe wartości w wychowaniu, w: F. Adamski (red.), dz. cyt., s. 131. 
Próba poszukiwania odpowiedzi na sformułowane powyżej pytanie w myśli Maritaina uwarunkowana jest jednak nie tylko faktem podjęcia przez niego niniejszej kwestii. Istotna jest także perspektywa, z jakiej się jej przygląda, a którą wyznaczają badania antropologiczne, epistemologiczne oraz etyczne, prowadzone w duchu filozofii tomistycznej. Odwołanie się do nich pozwala Maritainowi wyciągnąć wniosek, że nie każda edukacja liberalna może mieć charakter wyzwalający. Pasywnie i mechanicznie przyjmowane informacje mogą bowiem obciążać i ogłupiać umysł, a w konsekwencji-zamiast go rozwijać, a wraz z nim i ludzką wolność - mogą wywoływać w rozumie efekt podobny to tego, jaki przynosi wrzucenie dużej masy wilgotnego drewna do ognia - zamiast czynić ogień silniejszym, prowadzi do jego zagaszenia ${ }^{3}$. Owe badania prowadzą również do szeregu interesujących konstatacji, które warto uwzględnić, poszukując koncepcji edukacji liberalnej.

Rekonstrukcja poglądów Maritaina na temat edukacji liberalnej przeprowadzona zostanie w trzech etapach. Najpierw analizie poddane zostaną wnioski, do jakich dochodzi Maritain w ramach refleksji nad ludzką wolnością, zwłaszcza w aspekcie jej rozwoju, następnie zatrzymamy się nad uwarunkowaniami rozwoju wolności człowieka, by w trzecim punkcie na tle wcześniejszej prezentacji spróbować zrozumieć stanowisko Maritaina w kwestii liberal education. Całość rozważań dopełnią wnioski, jakie wynikają z badań Maritaina dla prowadzonych obecnie dyskusji nad kształceniem ogólnym, humanistycznym.

\section{Ludzka wolność w perspektywie rozwojowej}

Refleksja nad człowiekiem prowadzi Maritaina do stwierdzenia, że człowiek jest istotą wolną, przy czym - zagłębiając się w pisma francuskiego filozofa - dochodzimy również do wniosku, że owa wolność znajduje się w potencji i wymaga aktualizacji. Pierwsza teza, dotycząca wolności jako faktu, nie jest bezpośrednio związana z podjętym w niniejszym tekście problemem, nie ma zatem potrzeby, aby odtwarzać drogę myślową Maritaina do stwierdzenia wolności człowieka. Odwołajmy się jedynie do konstatacji, które wyrażają jego stanowisko. Maritain pisze: „Człowiek jest osobą, która trzyma we władzy samą siebie poprzez swój umysł i poprzez swoją wolę. Nie istnieje po prostu jako byt fizyczny. Posiada w sobie istnienie bogatsze

\footnotetext{
${ }^{3}$ Por. tenże, Education, s. 50.
} 
i szlachetniejsze, duchowe istnienie właściwe poznaniu i miłości"4. W innym zaś miejscu znajdujemy słowa: „Osoba to wszechświat o naturze duchowej, obdarzony wolnością wyboru i stanowiący tym samym całość niezależną wobec świata" . Dużo ważniejsza z punktu widzenia interesującego nas tematu jest kwestia rozwoju wolności w człowieku, czyli kwestia jej aktualizacji. Przyjrzyjmy się zatem, do jakich wniosków dochodzi francuski filozof, badając wolność w perspektywie rozwojowej.

Mówiąc o rozwoju wolności, należy określić jej kontekst w naturze ludzkiej. Charakteryzując ową naturę, Maritain wskazuje najpierw na duchowy wymiar człowieka, który decyduje o ludzkiej wolności i który uprawnia do nazwania człowieka osobą (a samego wymiaru duchowego osobowością). Równocześnie Maritain przyznaje, że osobowość jest tylko jednym z biegunów ludzkiego bytu. Drugim jest jednostkowość, której korzeniem jest materia. Człowiek jest więc nie tylko osobą, ale jest także materialną jednostką, fragmentem gatunku, skrawkiem fizycznego wszechświata, zwykłym punktem w bezmiernej sieci sił i oddziaływań, których prawu jest podporządkowany. Jego człowieczeństwo jest człowieczeństwem zwierzęcia. Człowiek podlega siłom fizycznym, kosmicznym, roślinnym i zwierzęcym, etnicznym, atawistycznym, dziedzicznym, ekonomicznym i historycznym ${ }^{6}$. Mówiąc o rozwoju wolności, należy zatem pamiętać, że chodzi o wolność człowieka - równocześnie osoby i jednostki - do którego odnoszą się słowa Maritaina: ,Jako indywidualności, podlegamy gwiazdom, jako osoby - panujemy nad nimi" kacją rozwoju osobowości, stawania się coraz bardziej osobą, którego przeciwieństwem jest stawanie się coraz bardziej jednostką: „Mogę się rozwijać w kierunku osobowości, inaczej mówiąc w kierunku opanowania i niezależności, właściwych duchowi, mocą którego istnieję. Albo też mogę rozwijać się w kierunku jednostkowości, inaczej mówiąc, w kierunku poddania się skłonnościom, które są we mnie obecne z racji materii i dziedziczności”"8.

W pismach Maritaina znajdujemy także dookreślenie tego, na czym polega stawanie się bardziej jednostką lub bardziej osobą. Według niego, stawać się coraz bardziej jednostką to stawać się coraz bardziej niewolnikiem

4 Tenże, Podmiotowość czlowieka, w: tenże, Pisma filozoficzne, Kraków 1988, s. 95.

5 Tenże, Humanizm integralny, Warszawa 1981, s. 7.

${ }^{6}$ Por. tenże, Od filozofii, s. 66; tenże, Osoba ludzka i społeczeństwo, w: F. Adamski (red.), dz. cyt., s. 329.

7 Tenże, Trzej reformatorzy. Luter, Kartezjusz, Rousseau, Warszawa-Ząbki 2005, s. 52.

${ }^{8}$ Tenże, Dynamika, s. 31; por. tenże, Education, s. 34. 
warunków, okoliczności, być niezdolnym do kierowania sobą, być tylko częścią. Taki profil posiada ludzki rozwój wówczas, gdy człowiek czyni z siebie centrum wszystkiego i żyje życiem niskich żądz i namiętności, podążając za tysiącem przemijających dóbr, które dają mu chwilową radość, i próbując je zdobywać tylko dla siebie ${ }^{9}$. Maritain zdaje sobie sprawę z tego, że zwłaszcza w zbiorowości człowiek w niewielkim stopniu żyje życiem prawdziwie ludzkim rozumu i wolności, a więc w pewnym sensie jest „,poddany gwiazdom” ${ }^{10}$. Stawanie się osobą posiada kierunek przeciwny: „dusza wznosi się ponad świat zmysłowy, wiąże się coraz ściślej przez rozum i wolę z tym, co stanowi życie ducha"11. O byciu osobą można zatem mówić jedynie wówczas, gdy życie rozumu i wolności przekłada się na opanowanie życia zmysłów i namiętności, czyli wówczas, kiedy człowiek staje się wolny w sensie wewnętrznym i duchowym ${ }^{12}$. W swoich poglądach Maritain nie deprecjonuje, oczywiście, cielesności. Nie uważa bowiem, aby rozwój osobowości polegał na „uśmierceniu” jednostkowości ${ }^{13}$. Jego zdaniem, stawanie się osobą wymaga od człowieka, „by dążył do uczynienia sił świata fizycznego narzędziami własnej wolności"14. Rozwój osoby to zatem osiągnięcie wolności w tych uwarunkowaniach, w których człowiek funkcjonuje, i z wykorzystaniem tych sił i środków - także materialnych - jakie zostały mu dane.

Mówienie o wolności domaga się jeszcze określenia kryterium, przy pomocy którego można stwierdzić, czy dany czyn jest manifestacją ludzkiej wolności, czy może wynikiem oddania się namiętnościom, które przynoszą chwilową radość. Owo kryterium - paradoksalnie - nie jest związane według Maritaina bezpośrednio z człowiekiem, ale z porządkiem rzeczywistości, która jest od człowieka niezależna, a do której odniesienia posiadają wymiar moralny. Dochodzimy w tym miejscu do związków między rozwojem człowieka jako osoby, którego integralną częścią jest rozwój wolności, a jego moralnością - człowiek manifestuje swoją osobowość, a więc także swoją wolność, wówczas gdy realizuje poprzez własne czyny dobro samo w sobie, tak zwane dobro godziwe - bonum honestum. Bardzo często realizacja owego dobra domaga się poświęcenia innych dóbr - użytecznych

${ }_{9}^{9}$ Por. tenże, Trzej reformatorzy, s. 56, 220; tenże, Osoba, s. 335-336; tenże, Dynamika, s. 31; tenże, Religia i kultura, w: tenże, Religia i kultura, Warszawa 2007, s. 48-49.

${ }^{10}$ Por. tenże, Humanizm, s. 79.

11 Tenże, Trzej reformatorzy, s. 56; por. tenże, Osoba, s. 335-336.

12 Por. tenże, Od filozofii, s. 67-68; tenże, Dynamika, s. 31; tenże, Religia, s. 48-49.

${ }_{13}$ Por. tenże, Osoba, s. 336; tenże, Dynamika, s. 31-33; tenże, Education, s. 35.

${ }^{14}$ Tenże, Humanizm, s. 3. 
czy przyjemnych. Może się zdarzyć, że dobro godziwe jest dla człowieka niekorzystne z punktu widzenia jego cielesnej jednostkowości. W każdym jednak przypadku czyni ono człowieka dobrym i sprawia, że człowiek spełnia się - staje się osobą ${ }^{15}$.

Nakreślona powyżej w dużym skrócie i uproszczeniu teoria człowieka, ze zwróceniem szczególnej uwagi na drogi rozwojowe ludzkiej wolności, rodzi pytanie o te czynniki, które mogą stymulować rozwój wolności oraz te, które ów rozwój przekreślają. Zatrzymajmy się zatem teraz na tym zagadnieniu.

\section{Uwarunkowania rozwoju wolności w człowieku}

Przytoczone już stwierdzenie, że ludzka duchowość opiera się na „poznaniu i miłości", prowadzi do wniosku, że podstawowym warunkiem rozwoju osobowości oraz implikowanego przez ów rozwój ujawniania się wolności jest rozwój intelektu. Intuicję tę potwierdzają słowa Maritaina, który mówi:

Wolność dziecka nie jest spontanicznością natury zwierzęcej, która od początku postępuje naprzód drogami określonymi przez instynkt. Wolność dziecka jest spontanicznością natury ludzkiej i rozumnej, i ta spontaniczność, charakteryzująca się pełną rozmachu nieokreślonością, ma wewnętrzną zasadę docelowego określania jedynie w rozumie, który nie jest jeszcze rozwinięty u dziecka ${ }^{16}$.

Poszukując uwarunkowań rozwoju wolności, należy zatem przyjrzeć się rozwojowi intelektualnemu, pytając, na czym miałby on polegać. Rozstrzygając z kolei tę kwestię, konieczne jest odniesienie do kontekstu moralnego ludzkiego działania, a zwłaszcza do wspomnianej już kwestii dobra godziwego, ponieważ - zdaniem Maritaina - rozwój osobowości, a tym samym i wolności, wpisany jest w ten kontekst.

Stawać się bardziej osobą można - zdaniem Maritaina - tylko przez realizację tak zwanego dobra godziwego. Aby określić, czym jest dobro godziwe, należy odnieść się do dobra ontologicznego, które związane jest z ko-

${ }^{15}$ Por. tenże, Dziewięć wyktadów o podstawowych pojęciach filozofii moralnej, Lublin 2001, s. 44-50; tenże, Od filozofii, s. 62.

${ }^{16}$ Tenże, Dynamika, s. 30. 
lei z prawem naturalnym. Pod tą ostatnią nazwą kryje się porządek, który wpisany jest w rzeczywistość i według którego coś jest odpowiednie a coś nieodpowiednie dla danego bytu, coś właściwe a coś niewłaściwe dla niego. Dobrem ontologicznym nazywane jest to, co jest odpowiednie dla danego bytu ${ }^{17}$. W przypadku człowieka możemy mówić na przykład o odpowiednim lub nieodpowiednim dla niego pożywieniu czy odpowiednim lub nieodpowiednim zachowaniu w kontakcie $\mathrm{z}$ wodą lub ogniem. Informacje o tym, co jest odpowiednie lub nieodpowiednie, powstają najpierw w doświadczeniu zmysłowym, a następnie przekładane są na określone idee ${ }^{18}$. Dobro moralne - dobro godziwe - związane jest $\mathrm{z}$ dobrem ontologicznym, ale nie jest $\mathrm{z}$ nim tożsame. O dobru moralnym mówimy, odnosząc się do szczególnego porządku, jakim jest spełnienie ludzkiego bytu. Dobre moralnie jest to, co prowadzi do istnienia człowieka jako wolnego podmiotu, co przynosi rozwój jego osobowości. Nie wszystkie dobra, które w porządku ontologicznym jawią się jako korzystne, ponieważ przynoszą przyjemność, w porządku moralnym okazują się dobre - niektóre zamiast prowadzić do rozwoju osobowości, przyczyniają się do jej zagubienia na rzecz jednostkowości ${ }^{19}$. Dobro moralne jest więc godne miłości i pożądania $\mathrm{z}$ dwóch względów: ze względu na nie samo, ale też ze względu na to, że czyni dobrym działający podmiot. Maritain jako przykład podaje ratowanie czyjegoś życia mimo zagrożenia własnego dobra. Wartość tego czynu wynika zarówno z wartości samego przedmiotu czynu, jak i z faktu, że czyni dobrym działający podmiot (podmiot staje się osobą, jeżeli podejmuje działanie, przełamując lęk związany $\mathrm{z}$ własną cielesnością) ${ }^{20}$. Gdy Maritain mówi o rozwoju rozumu, ma zatem na myśli taki rozwój, dzięki któremu dojrzewający człowiek nauczy się rozpoznawać dobro moralne - dobro, poprzez które człowiek może spełnić się jako osoba i którego realizacja ujawnia ludzką wolnośćc ${ }^{21}$. Co więcej, natura owego dobra sprawia, że jedynie rozum jest w stanie je rozpoznać. W konsekwencji to rozum staje się «miarą ludzkich czynów», miarą mierzącą 22 i to rozum powinien wyznaczać cele spontanicznej aktywności.

17 Por. tenże, Prawo naturalne i prawo moralne, w: tenże, Pisma, s. 249-250; tenże, Człowiek i państwo, Kraków 1993, s. 91-96.

18 Por. tenże, Dziewięć wykładów, s. 37-41.

19 Por. tenże, Osoba, s. 336.

${ }^{20}$ Por. tenże, Dziewięć wyktadów, s. 49-50, 83-84.

${ }^{21}$ Por. tenże, Dynamika, s. 32; tenże, Od filozofii, s. 68; tenże, Moralne, s. 132.

${ }_{22}$ Por. tenże, Prawo naturalne, s. 249; tenże, Dziewięć wykładów, s. 30; tenże, Religia, s. 59. 
Rozwój rozumu, w którym uczy się on rozpoznawać dobro moralne, co w konsekwencji warunkuje rozwój wolności, Maritain nazywa nabywaniem mądrości. Według francuskiego filozofa, mądrość:

to poznanie, które przenika i obejmuje rzeczy, posługując się ujęciami intelektualnymi najgłębszymi, najogólniejszymi i najpełniejszymi. Takie poznanie, które karmi się nie tylko wiedzą wyższą, lecz również ludzkim doświadczeniem duchowym, wykracza ponad wszelką dziedzinę spekulacji, gdyż ma do czynienia z rzeczywistościami, które przenikają wszystko, co jest, i z aspiracjami, które wynikają z samej natury i wolności człowieka ${ }^{23}$.

Specyfika mądrości jest lepiej widoczna, gdy spojrzymy na nią na tle wiedzy. Wiedza-nauka jest udoskonaleniem inteligencji poprzez poznanie, które opisuje rzeczywistość w kategoriach przyczyn i skutków. Sama w sobie jest ona piękna i dobra, wskazuje też na szlachectwo ducha ${ }^{24}$. Wiedza nie dorównuje jednak mądrości, ponieważ formułowana jest ze względu na użyteczność. Nie jest zatem w stanie wskazać na cel ludzkiego życia - cel jest czymś bardziej ostatecznym i zaspokajającym niż użyteczność, na którą wskazuje nauka. W przeciwieństwie do wiedzy mądrość jest odkryciem dróg spełnienia ludzkiego bytu ${ }^{25}$. Mądrość porządkuje ludzkie działania. Jej brak sprawia, że wiedza - sama w sobie dobra - może być wykorzystywana zarówno w dobrych, jak i w złych celach ${ }^{26}$. Przy czym wykorzystanie wiedzy w złych celach nie ujawnia wolności, ponieważ oznacza danie upustu cielesnym namiętnościom.

Podsumowując należy powiedzieć, że w swoich pismach Maritain wskazuje na nieodzowność rozwoju intelektu dla rozwoju osobowości i wolności. Co więcej, określa też, na czym polegać ma rozwój intelektualny. Równocześnie błędem byłoby postawienie znaku równości między rozwojem intelektu a rozwojem wolności. Maritain zdaje sobie bowiem sprawę, że w ostateczności to nie rozum, ale wola decyduje o moralnej jakości czynu. Innymi słowy, fakt, że rozum rozpoznaje dobro moralne, nie oznacza, że owo dobro zostanie przez człowieka zrealizowane ${ }^{27}$. To, ku czemu podążał będzie człowiek w swym czynie, zależne jest bowiem od dobra, które pociąga jego

\footnotetext{
${ }^{23}$ Tenże, Dynamika, s. 37; por. tenże, Education, s. 48.

${ }^{24}$ Por. tenże, Nauka i mądrość, Warszawa-Ząbki 2005, s. 18, 20, 33.

25 Por. tamże, s. 33.

${ }^{26}$ Por. tamże, s. 47, 88.

27 Por. tenże, Dziewięć wykładów, s. 93.
} 
wolę. Rozum odgrywa podstawową rolę w poznaniu, gdzie uzgadnia podmiotowy obraz rzeczywistości z rzeczą. W przypadku kierowania konkretnymi czynami nie chodzi jednak o zgodność z rzeczą, ale z pragnieniem ${ }^{28}$. Jak mówi Maritain, dyskutując z tezami Marcina Lutra: „przez wolę, a nie przez rozum jesteśmy dobrzy lub źli" ${ }^{29}$. Parafrazując można by powiedzieć, że przez wolę człowiek jest wolny, a nie przez rozum. Nie ma tu miejsca na głębsze przeanalizowanie tego zagadnienia, ale rekonstruując koncepcję edukacji liberalnej stworzoną przez Jacques’a Maritaina, należy pamiętać, że do ujawnienia się wolności wiedza jest równocześnie nieodzowna i niewystarczająca. Jej słabość wynika z faktu, że nie jest ona w stanie „pobudzić źródła miłości w głębinach ludzkiej niezależności”. Jej wartość wiąże się z kolei z tym, że broni miłości i czyni ją wolną, jeżeli ta już się pojawi ${ }^{30}$.

Chcąc dochować wierności poglądom Maritaina, powinniśmy również zauważyć, że zdaniem francuskiego filozofa ostatecznym warunkiem rozwoju osobowości oraz zawierającego się w nim rozwoju wolności jest miłość do Boga. Jego stanowisko w tej kwestii doskonale oddają słowa:

istotną przeszkodą w życiu moralnym jest egoizm a największą tęsknotą życia moralnego wyzwolenie; tylko miłość, będąca darem samym w sobie, może usunąć tę przeszkodę i spełnić tę tęsknotę. Miłości towarzyszy jednak egoizm, który w obawie, że wpadniemy w jej sidła, sprawia, że ci, których kochamy, stają się łupem naszej miłości [...]. Bóg jest jedyną istotą, do której miłość ludzka może dotrzeć i w niej pozostać - obejmując wszystkich innych ludzi, pozostaje wolną od egoistycznej miłości własnej ${ }^{31}$.

Maritain jest zatem przekonany, że bez miłości Boga rozwój człowieka prędzej czy później staje się rozwojem jednostkowości, prowadząc tym samym do zagubienia autentycznej wolności.

Przeprowadzone w niniejszym punkcie analizy pozwalają przyjrzeć się, jaką rolę w rozwoju wolności może odegrać liberal education. Pozwalają one z jednej strony uznać jej wartość, a z drugiej - nie przeceniać jej. Nawet najlepiej zaplanowana i przeprowadzona edukacja liberalna nie zagwarantuje bowiem, że w poddanym jej człowieku ujawni się wolność. Równocze-

${ }^{28}$ Por. tenże, Trzej reformatorzy, s. 73, 75-76; tenże, Od filozofii, s. 74-75.

29 Tenże, Trzej reformatorzy, s. 75.

${ }^{30}$ Por. tenże, Moralne, s. 141; tenże, Nauka, s. 188-189, 191. Maritain twierdzi „Roztropność, aby być cnotą czystą i prostą, potrzebuje miłości”. Tamże, s. 173.

31 Tenże, Moralne, s. 137. 
śnie analiza myśli Maritaina każe postrzegać liberal education jako warunek rozwoju wolności, ponieważ nieodpowiednio przygotowany umysł przekreśla niejako możliwość ujawnienia się wolności w ludzkim czynie. Co więcej, Maritain - mimo dostrzegania ograniczeń rozwoju intelektualnego - postuluje jednak skupienie się na nim. Krytykuje woluntaryzm, który ujawnia się jego zdaniem w teoriach, mówiących o wychowaniu woli, wychowaniu uczucia, kształtowaniu charakteru. Uważa, że:

Łatwo zepsuć i wypaczyć charakter, trudno go ukształtować. [...] Metody, które zamieniają szkołę w szpital, mający naprawiać i ożywiać wolę, podsuwać zachowania altruistyczne czy wpajać dobrą świadomość obywatelską, mogą być znakomicie obmyślone i psychologicznie doskonałe - nie zmniejsza to przeważnie ich zniechęcającej nieskuteczności ${ }^{32}$.

Należy zatem zachować respekt dla ducha i dla rodzącego się ludzkiego rozumu $^{33}$, apelując przede wszystkim do rozumu i wolnej woli dziecka ${ }^{34}$. Szkoły, uczelnie i uniwersytety - bezradne jeżeli chodzi o wspieranie rozwoju woli - powinny wzmacniać umysł ucznia, przyczyniając się w ten sposób do rozwoju wolności ${ }^{35}$. Zajmijmy się teraz bezpośrednio sformułowaną przez Maritaina koncepcją edukacji liberalnej.

\section{Liberal education w ujęciu Jacques'a Maritaina}

Na fundamencie przeprowadzonych powyżej analiz rodzi się pytanie, jak pokierować rozwojem intelektualnym, aby rozum nabywał mądrość, warunkując tym samym wolność działania konkretnego człowieka. Jest to tym samym pytanie o liberal education. Jak to zostało już stwierdzone we wstępie, Maritain formułuje koncepcję edukacji liberalnej w odniesieniu do filozofii tomistycznej. Zanim zajmiemy się bezpośrednio ową koncepcją, zatrzymajmy się zatem na moment nad pomagającą zrozumieć stanowisko Maritaina tomistyczną epistemologią. Naszymi przewodnikami w tym temacie będą Mieczysław Krąpiec i Stefan Swieżawski.

\footnotetext{
32 Tenże, Od filozofii, s. 74.

33 Por. tenże, Dynamika, s. 34.

34 Por. tenże, Od filozofii, s. 66.

${ }^{35}$ Por. tamże, s. 75, 78; tenże, Dynamika, s. 29; tenże, Moralne, s. 131.
} 
Refleksja w duchu filozofii tomistycznej prowadzi do ukazania ludzkiego poznania jako procesu znajdującego swoje źródło w rzeczywistości materialnej, dostarczającej wrażeń poznawczym władzom zmysłowym, oraz dopełniającego się na poziomie umysłowym. Intelekt, czyli umysłowa władza poznawcza, uzależniony jest - zdaniem tomistów - od treści dostarczonych przez zmysły ${ }^{36}$. Przekonanie to wynika z faktu, że wada którejś z władz zmysłowych uniemożliwia intelektowi wyrobienie sobie właściwych dla tego zmysłu treści ${ }^{37}$. Stwierdzenie uwarunkowania działalności intelektu danymi pochodzącymi ze zmysłów nie oznacza zdeterminowania intelektu poznaniem zmysłowym. Po pierwsze dlatego, że charakter uzyskanej czy wytworzonej wiedzy jest jakościowo różny od samych zmysłowych wrażeń, czyli poznanie, dokonane przez intelekt, jest istotnie różne od struktury aktów poznawczych zmysłowych ${ }^{38}$. A po drugie dlatego, że intelekt jest w stanie odkryć istnienie rzeczywistości, które nie są zmysłowo dostępne, takich jak relacje czy braki. Za przykład może też posłużyć Absolut, rozumiany jako pierwsza przyczyna, którego istnienie wyprowadzane jest z refleksji nad rzeczywistością i jej przygodnością.

Namysł nad działalnością intelektu na danych dostarczonych przez zmysły doprowadził ponadto do wyodrębnienia trzech rodzajów działań umysłowo-poznawczych. Pierwszym z nich jest tworzenie pojęć, drugim sądzenie, natomiast trzecim rozumowanie. Tworzenie pojęć polega na odmaterializowaniu i uogólnieniu wyobrażeń, docierających z poznawczych władz zmysłowych $^{39}$. Sądzenie jest zespalaniem pojęć ze sobą, w efekcie czego powstają zdania, które mają treść pozytywną (orzekają, że coś jest takie a takie) lub negatywną (orzekają o czymś, że coś nie jest takie a takie). Rodzajem sądu jest także sąd egzystencjalny, w którym stwierdza się, że coś jest, istnieje. Najbardziej skomplikowanym działaniem jest łączenie sądów ze sobą. Nazywane jest ono rozumowaniem. W rozumowaniu następuje przejście od jednego sądu do innego, z racji wywodzi się następstwa itd. Efektem rozumowania są różnego rodzaju teorie ${ }^{40}$.

36 Por. S. Swieżawski, Św. Tomasz na nowo odczytany, Poznań 1995, s. 162-163; M. A. Krąpiec, Ja-człowiek, Lublin 2005, s. 188-189.

37 Por. M. A. Krąpiec, dz. cyt., s. 206.

38 Por. tamże.

39 Proces, w wyniku którego rodzą się pojęcia, nazywany jest abstrakcją: „Proces abstrakcji jest to oddzielanie w wyobrażeniach tych wszystkich elementów, które są czasowoprzestrzenne, i wyłuskiwanie z tych wyobrażeń wspólnej treści - pojęcia”. S. Swieżawski, dz. cyt., s. 178.

${ }^{40}$ Por. M. A. Krąpiec, dz. cyt., s. 180-187; S. Swieżawski, dz. cyt., s. 181-182. 
Dla zagadnienia rozwoju intelektu szczególnie istotne jest tworzenie sądów i rozumowanie oraz właściwe relacje między nimi. Sądy tworzone są na drodze kontemplacji rzeczywistości. W sądzie stwierdza się na przykład, czy jakieś działanie wyrządziło komuś krzywdę, czy przyczyniło się do jego dobra. Trudniejszą i wyżej wartościowaną czynnością jest rozumowanie. Prowadzi ono do ujmowania różnego rodzaju zależności w postaci teorii oraz porównywania ich ze sobą. Mimo że rozumowanie uważane jest za doskonalsze od sądzenia, może ono rodzić wiele błędów poznawczych. Aby zrozumieć, dlaczego tak się dzieje, należy przyjrzeć się samemu rozumowaniu. Charakteryzując je, Krąpiec przywołuje myśl Étienne’a Gilsona, który pisze, że w dziedzinie spekulatywnej duch abstrakcji skłania do zastępowania definiowanej rzeczy definicją, a w konsekwencji do iluzji, że można powiększyć wiedzę, dedukując wnioski z już sformułowanych definicji, zamiast jak najczęściej powracać do rzeczy, z których wyabstrahowane zostały istoty rzeczy oraz ich definicje ${ }^{41}$. Innymi słowy, w czynności rozumowania może dojść do oderwania intelektu od rzeczywistości i do operowania na samych ideach. Czy to stwierdzenie oznacza deprecjację rozumowania? Absolutnie nie, rozumowanie stanowi ważną dla człowieka umiejętność, ale pod warunkiem, że jest nieustannie kontrolowane i korygowane przez sądzenie. Sądy są ważne nie tylko jako materiał dla rozumowania, ale także mają one kształtować rozumowanie.

Tymczasem, jak podkreśla Swieżawski, kultura europejska wyrosła $\mathrm{z}$ rozkwitu rozumowania przy zaniedbaniu sądzenia ${ }^{42}$. Leżące $u$ fundamentów kultury europejskiej przekonania Krąpiec charakteryzuje w następujących słowach:

Uważano, że intelektualne poznanie adekwatnie wyraża się w idei. Dlatego wszelkie operacje poznawcze w człowieku sprowadzono do produkcji nowej idei. Drogi produkcji tej nowej idei były rozmaite: bądź przez abstrakcję, bądź przez sądy, bądź przez rozumowania. Wszystkie jednak operacje poznawcze człowieka miały się kończyć na produkcji nowej idei lub udoskonaleniu idei już posiadanej. Człowiek im bardziej mądry, tym mniej potrzebuje szczegółowych idei, gdyż w ideach „wyższych” widzi więcej, aniżeli ludzie mniej mądrzy zdołają dostrzec w całym zbiorze idei szczegółowych ${ }^{43}$.

\footnotetext{
${ }^{41}$ Por. M. A. Krąpiec, dz. cyt., s. 192.

42 Por. S. Swieżawski, dz. cyt., s. 182.

${ }^{43}$ M. A. Krąpiec, dz. cyt., s. 195.
} 
Odpowiedzialnością za przewartościowanie rozumowania nad sądzeniem Krąpiec obarcza „ducha abstrakcji” i „teologizm platoński”. Stwierdza również, że jego konsekwencją jest polityczny i społeczny nieład, nietolerancja i fanatyzm ${ }^{44}$.

Powyższy wywód, dotyczący epistemologii tomistycznej, łatwiej było zrekonstruować poprzez odwołanie do analiz Swieżawskiego i Krąpca niż do dzieł Maritaina. Usprawiedliwieniem dla takiego działania jest jednak osadzenie badań wszystkich trzech myślicieli w tomizmie egzystencjalnym, którego prekursorem był Maritain. Należy również dodać, że w pismach Maritaina można znaleźć słowa, wskazujące na zgodność z poglądami przywołanych filozofów. Maritain stwierdza, że uznanie znaczenia rozumu nie może prowadzić do przecenienia jego roli, czyli do racjonalizmu, przyznającego rozumowi prawo nie tylko do mierzenia, ale także do kreowania wartości. $\mathrm{W}$ następujący sposób wskazuje on na niebezpieczeństwa związane z racjonalizmem:

Istota racjonalizmu polega na tym, że z rozumu ludzkiego i jego zawartości ideologicznej czyni się miarę tego, co jest. To istne szaleństwo! Wszak rozum ludzki nie posiada innej zawartości niż ta, którą otrzymał od rzeczy. Tego rodzaju inflacja rozumu jest oznaką i przyczyną wielkiej słabości. Osłabiony rozum traci zdolność ujmowania rzeczywistości i po pewnym okresie zarozumiałości musi abdykować i wpada wtedy w antyintelektualizm, woluntaryzm, pragmatyzm. [...] Realizm, jako że szanuje przyrodzoną pokorę rozumu, pozwala na jego zwycięski pochód w dziedzinie poznania bytu ${ }^{45}$.

Przekonanie co do tego, że rozumowanie powinno posiadać silne podstawy w dziedzinie sądów, jest fundamentem, do którego odwołuje się Maritain, proponując własną koncepcję liberal education. Jest on przekonany, że edukacja liberalna powinna rozwijać najpierw zdolność sądzenia, a następnie zdolność rozumowania. Przyjrzyjmy się temu stanowisku, zatrzymując się najpierw nad rozplanowaniem edukacji liberalnej. Maritain wyróżnia trzy etapy w edukacji człowieka: 1) edukację podstawową/elementarną, 2) edukację humanistyczną (obejmującą szkołę średnią i college - w swojej pracy odnosi się do amerykańskiego systemu kształcenia) oraz 3) studia wyższe. Odzwierciedlają one, jego zdaniem, nie tylko okresy w dojrzewaniu człowieka, ale odnoszą się także do trzech rodzajów uzyskiwanej w trakcie

${ }^{44}$ Por. tamże, s. 192-193.

45 J. Maritain, Trzej reformatorzy, s. 127-128. 
rozwoju intelektu wiedzy ${ }^{46}$. Świat dziecka jest światem wyobrażeń, które pojawiają się powoli w rozumie, stając się fundamentem dla pojęć. Owe wrażenia nie są jeszcze uporządkowane i mieszają się ze sobą w świecie wyobraźni ${ }^{47}$. Na tym etapie dziecku potrzebna jest edukacja elementarna, w której kontakt z rzeczywistością przyczynia się do tworzenia wyobrażeń i kształtujących się na ich podstawie pojęć. Rozwój intelektualny nastolatka związany jest - zdaniem Maritaina - z tworzeniem sądów. Ów rozwój powinien być zatem inspirowany i stymulowany poprzez prawdę. Nastolatek powinien zbliżać się do rzeczywistości, poznawać ją, a nie przyswajać sobie teorie, czyli struktury intelektualne. Poznanie prawdy Maritain przeciwstawia erudycji ${ }^{48}$. Czasem zetknięcia $\mathrm{z}$ teoriami oraz nauki operowania nimi jest dopiero czas studiów wyższych - jest to etap rozwoju rozumowania. Błędem - w opinii Maritaina - jest próba napełnienia umysłu dziecka nauką/wiedzą właściwą dla osób dorosłych, będących ekspertami w różnych dziedzinach ${ }^{49}$. Edukację liberalną Maritain umieszcza przede wszystkim na poziomie college'u, gdzie powinna - jego zdaniem - być rozwijana zdolność sądzenia, oraz na poziomie studiów wyższych, gdzie powinno się dążyć do zbudowania jedności między różnymi dziedzinami wiedzy, a więc gdzie dokonuje się rozwój rozumowania i operacje na teoriach, ideach.

Edukacja liberalna na poziomie college'u ma na celu przede wszystkim wprowadzenie dojrzewającego człowieka w wielkie osiągnięcia ludzkiego umysłu, w różne dziedziny wiedzy, przy czym chodziłoby przede wszystkim o to, aby nastolatek zrozumiał ich sens, a nie stawał się ekspertem w owych dziedzinach ${ }^{50}$. Maritain pisze, że chodzi o to, aby młody człowiek zrozumiał sens muzyki, nie stając się muzykiem, czy sens fizyki, nie stając się fizykiem ${ }^{51}$. Maritain określa też, w jakie dziedziny powinien - jego zdaniem - zostać wprowadzony nastolatek. Pierwszy rok nauczania powinien zostać poświęcony matematyce oraz poezji, obejmując następujące przedmioty (kolejność wskazuje na znaczenie): 1) matematykę, literaturę, poezję; 2) logikę; 3) języki obce i historię cywilizacji. Dla drugiego roku wiodące powinny być nauki przyrodnicze oraz sztuki piękne, a program powinien objąć: 1) fizykę i nauki przyrodnicze; 2) sztuki piękne, matematykę, literaturę i poezję; 3) historię

\footnotetext{
46 Por. tenże, Education, s. 58, 60.

${ }^{47}$ Por. tamże, s. 60-61.

${ }^{48}$ Por. tamże, s. 62

49 Por. tamże, s. 59.

${ }^{50}$ Por. tamże, s. 63.

51 Por. tamże.
} 
nauki. W trzecim roku uczeń powinien zmierzyć się z filozofią, studiując: 1) metafizykę, filozofię przyrody, teorię poznania, psychologię (rozumianą jako antropologia); 2) fizykę i nauki przyrodnicze; 3) matematykę, literaturę i poezję oraz sztuki piękne. W ostatnim roku nauki uwaga powinna zostać skupiona na etyce i filozofii politycznej, a program powinien objąć: 1) etykę, politykę i filozofię społeczną; 2) fizykę i nauki przyrodnicze; 3) matematykę, literaturę, poezję, sztuki piękne, historię cywilizacji i historię nauki. W przypisie dodaje także, że edukacja liberalna opcjonalnie powinna zostać poszerzona o teologię, której w dalszej części książki poświęca dużo więcej uwagi ${ }^{52}$.

Sam program nauczania w college'u nie do końca oddaje specyfikę sformułowanej przez Maritaina propozycji edukacji liberalnej na tym etapie. Aby ją odkryć, należy przyjrzeć się temu, jak powinny być nauczane poszczególne przedmioty. Francuski filozof podkreśla, że chodzi przede wszystkim o to, by umysł przylgnął do obiektywnej rzeczywistości, gdyż owo przylgnięcie buduje wyzwalającą moc ${ }^{53}$. Drogą do tego ma być chociażby lektura wielkich dzieł literatury, która pozwoli dojrzewającemu umysłowi zebrać wiedzę na temat człowieka i zmierzyć się z ważnymi egzystencjalnie pytaniami. Dzieła literatury proponują przeżycie prawdziwej przygody duchowej, zapraszając do spotkania z wewnętrznym światem jakiegoś człowieka, a w konsekwencji pomagają odkryć, czym jest honor, litość, rozpacz, godność człowieka i jego ducha, wielkość ludzkiego przeznaczenia, miłość i miłosierdzie, uwikłanie dobra i zła czy miłość rodzaju ludzkiego (caritas humani generis $)^{54}$. Przeciwieństwem lektury wielkich dzieł literatury jest czytanie i uczenie się z podręczników, które skupiają się na praktycznych błahostkach i czynią z człowieka ofiarę konieczności «bycia poinformowanym $»^{55}$. Przekonania Maritaina dobrze oddają słowa:

najlepszym środkiem do tego, by nie być książkowym, jest unikać jak dżumy podręczników i tekst-book'ów, nawet podręczników wiedzy eksperymentalnej, natomiast czytać książki, czytać je namiętnie i łapczywie; zrozumieć wreszcie [...], że studium życia konkretnego staje się pułapką, jeśli rozprasza ono uwagę dorosłego czy dziecka na „,praktycznych” błahostkach, przepisach psychotech-

\footnotetext{
52 Por. tamże, s. 67-68.

${ }^{53}$ Por. tamże, s. 44.

${ }^{54}$ Por. tenże, Moralne, s. 142; tenże, Education, s. 68-69.

${ }^{55}$ Por. tenże, Dynamika, s. 35-36.
} 
nicznych i nieskończonej liczbie utylitarnych czynności wbrew autentycznemu, konkretnemu życiu rozumu i duszy ${ }^{56}$.

Podobny cel wpisany jest $\mathrm{w}$ nauczanie filozofii, która powinna przede wszystkim budzić rozum, a nie przekonywać do określonego systemu, stąd Maritain postuluje czytanie na przykład dialogów Platona, choć daleki jest od przyznania słuszności platonizmowi ${ }^{57}$. Zdaniem Maritaina, ani bogaty materiał teoretyczny, wielość różnego rodzaju informacji i erudycja, ani znajomość metod pracy intelektualnej nie przyczynią się do zbudowania wolności w człowieku, jeżeli nie zostanie w nim obudzona duchowa natura ${ }^{58}$.

Interesujące jest stanowisko Maritaina na temat włączenia w program nauczania także teologii. Uważa on bowiem, że kwestie teologiczne i kontrowersje z nimi związane (dotyczące zwłaszcza relacji między naturą i łaską) przenikały rozwój kultury i cywilizacji zachodu i cały czas pracują w jej głębi. Bez znajomości teologii nie sposób zatem zrozumieć ani historii intelektualnej wieków XVI, XVII czy XVIII, reformacji i kontrreformacji, wewnętrznego kształtu społeczeństw, na przykład społeczeństwa angielskiego, czy idei praw człowieka, ani obecnego czasu oraz znaczenia jego wewnętrznych konfliktów ${ }^{59}$.

Za wprowadzeniem teologii do programu nauczania zdaje się przemawiać jeszcze jeden argument. Celem edukacji liberalnej jest - według Maritaina - nabycie mądrości. Francuski filozof wyróżnia jednak różne rodzaje mądrości. W jego pismach pojawia się zestawienie mądrości hinduskiej, greckiej oraz mądrości Starego Testamentu. Mądrość hinduska ma w jego opinii słuszny kierunek - jej celem jest osiągnięcie boskiej wolności, czyli jest mądrością zbawienia. Jej wadą jest jednak to, że upatruje możliwości osiągnięcia wolności w ascetycznym i mistycznym wysiłku natury ludzkiej, wskazuje na szereg przepisów i metod doskonalenia się i kontemplacji, których ostatecznym wykwitem jest buddyzm ${ }^{60}$. Mądrość grecka nie posiada tego kierunku, nie jest mądrością zbawienia - jest to mądrość tego świata - dąży do racjonalnego poznania wszechświata, do poznania bytu jako bytu i jego przyczyn. Nie jest jednak w stanie odpowiedzieć człowiekowi na

\footnotetext{
56 Tenże, Od filozofii, s. 71.

57 Por. tenże, Education, s. 71-73.

58 Por. tamże, s. 42-43.

${ }^{59}$ Por. tamże, s. 73-74.

${ }^{60}$ Por. tenże, Nauka, s. 22-23; tenże, Wplyw chrześcijaństwa na filozofię moralna, w:
} tenże, Pisma, s. 219-220. 
najważniejsze pytanie - nie potrafi wskazać, jak osiągnąć własne spełnienie. W konsekwencji schodzi na manowce, ponieważ prowadzi do zwątpienia W możliwości mędrca ${ }^{61}$. Mądrość Starego Testamentu jest - podobnie jak mądrość hinduska - mądrością zbawienia i wyzwolenia; wskazuje bowiem, na czym polega osiągnięcie przez człowieka jego osobowej pełni. W przeciwieństwie jednak do mądrości hinduskiej nie twierdzi, że człowiek może się spełnić dzięki własnemu wysiłkowi. Stoi ona na stanowisku, że osobowość ludzka może osiągnąć zbawienie - własną pełnię - tylko dzięki osobowości boskiej, która jej się oddaje ${ }^{62}$. Wynika stąd, że poszukiwanie mądrości domaga się czerpania nie tylko z ludzkiej refleksji, ale także ze źródeł religijnych.

W opinii Maritaina nowożytna filozofia - po zakwestionowaniu wartości danych płynących z religii - stanęła bezradna wobec pytania o spełnienie ludzkiego istnienia i zadowoliła się analizami praktycznych kwestii ${ }^{63}$. Dokonujący się w tym samym czasie rozwój nauk szczegółowych przyczynił się do tego, że filozofia zaczęła analizować i odzwierciedlać aktualne stany wiedzy. Przy czym nauka dąży do opanowania rzeczywistości materialnej. W konsekwencji świat humanistyczny został podporządkowany bogactwom jako swemu najwyższemu celowi. Tendencja ta ujawnia się zwłaszcza w deprecjonowaniu sensu ubóstwa ${ }^{64}$. Ubóstwo, ascetyzm w korzystaniu $\mathrm{z}$ dóbr materialnych nabierają bowiem sensu, gdy na ludzkie życie patrzy się w szerszej niż materialistyczna perspektywie. Stąd, pisząc o edukacji liberalnej, Maritain stwierdza: „Jestem przekonany, że jednym z głównych zadań naszych czasów jest rozpoznanie zarówno różnicy, jak i organicznej relacji między teologią, mającą podstawy w wierze, i filozofią, mającą fundament w rozumie" ${ }^{\prime 65}$.

${ }^{61}$ Por. tenże, Nauka, s. 26-27; tenże, Wpływ, s. 220-221.

${ }^{62}$ Por. tenże, Nauka, s. 29-31; tenże, Wplyw, s. 221-222; tenże, Człowiek i ludzki los, w: tenże, Pisma, s. 399-405.

${ }^{63}$ Por. tenże, Nauka, s. 43-45, 89-90; tenże, Trzej reformatorzy, s. 124.

${ }^{64}$ Przekonania Maritaina odzwierciedlają bardzo wymowne słowa: „Ubogie środki, sens ubóstwa jako oznaki najwyższego poznania i jako oznaki najmądrzejszego ustroju ekonomicznego, są zastąpione przez bogate środki i przez powszechną żarłoczność. Jest rzeczą bardzo znamienną, że panowanie nauki podniesionej do godności bóstwa i panowanie pieniądza miały swoją pierwszą zwiastującą jutrzenkę w jednej i tej samej godzinie, w zaraniu nowożytnego świata”. Tenże, Nauka, s. 46.

${ }^{65}$ Tenże, Education, s. 82. 
Maritain uważa, że edukację humanistyczną powinien otrzymać każdy, zanim wejdzie w etap dorosłości, argumentując to dwoma względami. Po pierwsze, uważa, że wprowadzanie specjalizacji na poziomie college'u jest przemocą na świecie młodego człowieka ${ }^{66}$, a po drugie, jest przekonany, że postęp w przygotowaniu zawodowym, technicznym i naukowym będzie szybszy i lepszy, jeżeli wybór dalszej edukacji zostanie poprzedzony edukacją liberalną i uniwersalną. Edukacja młodego człowieka nie zostanie bowiem zniszczona przez niedojrzałą specjalizację ${ }^{67}$.

Edukacja liberalna powinna - zdaniem Maritaina - znaleźć dopełnienie w kształceniu uniwersyteckim. Na czym miałaby ona polegać na tym poziomie kształcenia? Jego zdaniem, od każdego studenta powinno się wymagać, aby - bez względu na wybraną przez niego specjalizację - osiągnął pewien poziom sprawności w dziedzinach, które tworzą serce uniwersyteckiego życia. Każdy student powinien zatem być zobowiązany do uczęszczania na określoną ilość kursów czystej, uniwersalnej wiedzy. Wymusi to też na instytutach podjęcie głębszej współpracy. Maritain wyraża pogląd, że nie jest możliwe pożyteczne wykorzystanie wiedzy technicznej ani osiągnięć nauk praktycznych bez dobrego przygotowania ogólnego, bez pogłębionego rozumienia człowieka i otaczającej go rzeczywistości ${ }^{68}$.

$\mathrm{Z}$ zaproponowanej przez Maritaina koncepcji liberal education wynika, że zadaniem tego typu kształcenia jest przede wszystkim zbudowanie pewnej jedności wiedzy w człowieku. Nie może ona powodować rozproszenia wiedzy i nieprzystawalności wiedzy z jednej dziedziny do drugiej. Jedność jest wymagana, jeżeli celem edukacji jest osiągnięcie dojrzałości przez człowieka. Zdaniem Maritaina, jeżeli człowiek nie przezwycięży wewnętrznej wielości sił, a szczególnie różnych prądów wiedzy i wierzeń oraz różnych energii życiowych, które grają w jego umyśle, będzie on nieustannie bardziej sługą niż wolnym człowiekiem ${ }^{69}$. Jak twierdzi Maritain, nie chodzi o to, „by edukacja, elementarna czy wyższa, miała poświęcić się uczynieniu dziecka czy młodego człowieka mędrcem; powinna ona poświęcić się wyposażeniu ich umysłów w wiedzę żywą i uporządkowaną, która pozwoli im postępować ku mądrości, kiedy osiągną wiek dorosły"70.

\footnotetext{
66 Por. tamże, s. 64.

67 Por. tamże, s. 63.

68 Por. tamże, s. 80.

${ }^{69}$ Por. tamże, s. 45-49.

70 Tenże, Dynamika, s. 38.
} 


\section{Wnioski}

Przeprowadzony przez Jacques'a Maritaina namysł nad ludzką wolnością, jej rozwojem, jego uwarunkowaniami związanymi z rozwojem intelektu i wreszcie nad edukacją liberalną wywołuje szereg refleksji i pytań. Z jednej bowiem strony Maritain wyraża przekonanie co do konieczności zachowania i wzmocnienia edukacji liberalnej dojrzewającego człowieka, a z drugiej strony - bazując na filozofii tomistycznej - formułuje szereg wniosków odnośnie do kształtu owej edukacji, koniecznych do zrealizowania, jeżeli ta ma faktycznie prowadzić do kształtowania wolności wychowanka. Spróbujmy odczytać niektóre z nich w odniesieniu do współczesnej rzeczywistości edukacyjnej, pomijając przy tym kwestię samej wartości edukacji liberalnej.

1) Z przemyśleń Maritaina wynika, że edukacja liberalna jest praktycznie jedyną możliwością wspierania dojrzewającego człowieka w osiąganiu wolności, a równocześnie nie gwarantuje ona, że owa wolność zostanie osiągnięta. O osiągnięciu wolności decydują w ostateczności inne czynniki - przede wszystkim rozwój miłości w woli, w tym rozwój miłości Boga. Aby zobrazować tezę, wysuwaną przez Maritaina, odwołajmy się do miłości rodzica do dziecka. Rozwój intelektualny może pomóc owej osobie w określeniu, jakie działania w odniesieniu do dziecka są dobre, a jakie złe. Miłość dziecka (jako odniesienie woli a nie rozumu) sprawia, że rodzic podejmuje owe działania, nawet jeżeli wymagają one poświęcenia wielu dóbr osobistych (czego nie zrobiłby prawdopodobnie w odniesieniu do innego dziecka). Wykazuje się zatem wolnością w znaczeniu niezdeterminowania czynnikami cielesnymi. Miłość dziecka może jednak stać się miłością egoistyczną, co objawia się wycofaniem jej, gdy dziecko zaczyna działać wbrew rodzicom, albo ograniczaniem wolności dziecka, nawet wtedy gdy osiąga ono dojrzałość. Miłość egoistyczna świadczy w gruncie rzeczy o nieosiągnięciu przez rodziców pełnej wolności. Dopiero miłość Boga (w którą wpisana jest akceptacja cierpienia) przezwycięża egoizm i umożliwia osiągnięcie pełnej wolności w miłości, nawet jeżeli dziecko nie podąża drogą dobrą z punktu widzenia rodziców.

2) W edukacji liberalnej konieczne jest zachowanie właściwych proporcji między rozwojem sądzenia a rozwojem rozumowania. Przeakcentowanie rozumowania może bowiem prowadzić do tego, że poddany takiej edukacji dojrzewający człowiek najpierw nie będzie w stanie odróżnić w różnego rodzaju teoriach danych pochodzących z rzeczywistości od elementów dodanych, niekiedy będących logiczną teorią, a niekiedy posiadających prowe- 
niencję ideologiczną, a w następstwie tego porządkował będzie własne życie oraz działalność zawodową według przyjmowanych teorii. Pojęcie edukacji liberalnej, jak się okazuje, jest pojęciem niezwykle pojemnym, podatnym na przyjęcie także treści ideologicznych. Na czym miałaby zatem polegać w opinii Maritaina - edukacja liberalna, jeżeli chodzi o rozwój sądzenia? Wczytując się w pisma francuskiego filozofa, dochodzi się do wniosku, że to przede wszystkim odkrywanie człowieka i jego doświadczenia. Maritain wskazuje, że chodzi o zjawiska honoru, godności, litości, miłosierdzia. Można by do tej listy dopisać cały szereg innych zjawisk, takich jak: poczucie własnej słabości, przygodności własnego bytu; konieczność przebaczenia zarówno sobie, jak i innemu człowiekowi; doświadczenie wewnętrznego rozdarcia między dążeniem do dobra przyjemnego a powinnością rezygnacji $\mathrm{z}$ niego na rzecz dobra godziwego; poczucie winy, wynikające $\mathrm{z}$ realizacji dobra przyjemnego, które implikuje krzywdę wyrządzoną innemu człowiekowi itd. Wiele teorii, w tym teorii pedagogicznych, ignoruje zupełnie te zjawiska, co stanowi świadectwo, że zrodziły się one na fundamencie przewartościowania rozumowania nad sądzeniem. W edukacji liberalnej chodzi zatem - według Maritaina - o nawiązanie relacji umysłu z rzeczywistością, a nie o zarzucanie umysłu różnego rodzaju teoriami, które kompilowane prowadzą do oderwania umysłu od rzeczywistości i stworzenia w nim wyimaginowanego świata.

3) Interesujące stanowisko zajmuje Maritain w kwestii włączenia treści teologicznych w program edukacji liberalnej. Dla wielu osób jakiekolwiek odniesienie do Boga jest równoznaczne z nienaukowością i stawiane w opozycji do rozumu (jak również prowadzące do swoistego zniewolenia). Tymczasem Maritain postrzega sferę religijną jako ważny wymiar życia ludzkiego i uważa, że teologia jest konieczna do rozumowego wyjaśnienia doświadczenia religijnego oraz stymulowania rozumności i wynikającej z niej wolności człowieka. Oceniając słuszność tego stanowiska, odwołajmy się do coraz powszechniejszych postaw fundamentalistycznych. Przyglądając się wzrastającej liczbie takich postaw, także w sferze religijnej, można by zadać pytanie, na ile przyczyną ich popularności jest obecność, a na ile wyłączenie treści teologicznych poza margines współczesnej edukacji. Zauważmy jednak, że człowiek poddający sferę religijną refleksji w ramach studium teologii rozumie, że wiara rodzi się pod wpływem łaski i dlatego nikt nie może zostać zmuszony do przyjęcia wiary, co prowadzi do tolerancji religijnej. Osoby o poglądach fundamentalistycznych zdają się w ogóle tego nie rozumieć. Zatem to niezrozumienie sfery religijnej i w konsekwencji nieuporządkowanie jej przez rozum może skutkować fideizmem, co w praktyce prze- 
kłada się na postawy fundamentalistyczne i na bezrefleksyjne wykonywanie poleceń przywódców religijnych. Wyrugowanie edukacji religijnej z obszaru edukacji prowadzi do tego, że dojrzewającemu człowiekowi poddawanemu edukacji liberalnej w ramach wspierania rozwoju jego wolności nie pozwala się skorzystać z dorobku kultury europejskiej w obszarze refleksji nad wiarą i religią. Skazany zostaje tym samym na konieczność samodzielnego poszukiwania albo działania instynktownego w sferze religijnej, co może skutkować jego zniewoleniem.

Podjęte w niniejszym tekście rozważania stanowią jedynie głos w dyskusji nad edukacją liberalną i nie stanowią z pewnością podstaw do kompleksowej odpowiedzi na pytanie, jaki kształt powinna ona otrzymać. Analizy, jakie przeprowadził Maritain, prowadzą jednak niewątpliwie do interesujących wniosków, których nie sposób zignorować, projektując przebieg współczesnej edukacji.

\section{Liberal education according to Jacques Maritain (Summary)}

A specific character of the concept of liberal education formulated by Maritain is connected to the fact that the French philosopher refers there to anthropological, epistemological and ethical research conducted in the spirit of thomistic philosophy. Therefore, the article first presents Maritain's thoughts on human freedom which develops together with human personality revealing; still, this can be destroyed if human development leads towards individuality. Subsequently, the conditionings of freedom development was analysed, with the focus both on the development of mind and the development of will, also with the reference to religious development. In this context, the third section includes analyses of liberal education formulated by Maritain, where; according to him, one must maintain balance between the development of judgement, which should take place in college, and the development of reasoning understood as learning how to use judgements within university education. The conclusions emphasize not only the necessity of taking advantage of liberal education, but also indicate its actual role in the process of supporting the development of learner's freedom (it is often overvalued). One can also find a discussion there concerning the principles of liberal education in relation to judging and reasoning according to Maritain, and references to theological issues included in this education, which is specific for the French philosopher.

Keywords: Maritain; freedom; liberal education; judging; reasoning. 


\section{Liberal education w ujęciu Jacques'a Maritaina (Streszczenie)}

Specyfika sformułowanej przez Maritaina koncepcji liberal education związana jest z faktem, że francuski filozof odwołuje się w niej do badań antropologicznych, epistemologicznych i etycznych, prowadzonych w duchu filozofii tomistycznej. W artykule przedstawione zostały więc najpierw przemyślenia Maritaina na temat ludzkiej wolności, która rozwija się wraz z ujawnianiem się ludzkiej osobowości, ale może zostać zniszczona, jeżeli rozwój człowieka poprowadzony zostanie w kierunku jednostkowości. Następnie analizie poddane zostały uwarunkowania rozwoju wolności, wśród których zwrócono uwagę zarówno na rozwój rozumu, jak i na rozwój woli, odnosząc się także do rozwoju religijnego. W tym kontekście w punkcie trzecim umieszczono analizy sformułowanej przez Maritaina koncepcji liberal education, w której należy zachować - zdaniem francuskiego filozofa - równowagę między rozwojem sądzenia, który powinien dokonać się na poziomie college’u, jak i rozwojem rozumowania, rozumianego jako operowanie na sądach, który powinien dokonać się w ramach kształcenia uniwersyteckiego. We wnioskach autor zwraca uwagę nie tylko na konieczność prowadzenia liberal education, ale także wskazuje na jego rzeczywistą rolę w procesie wspierania rozwoju wolności wychowanka (często jest ona przeceniana). Omawia też, na czym - według Maritaina - powinna polegać edukacja liberalna w odniesieniu do sądzenia i rozumowania, oraz odnosi się do charakterystycznego dla francuskiego filozofa włączenia w zakres tej edukacji kwestii teologicznych.

Słowa kluczowe: Maritain; wolność; liberal education; sądzenie; rozumowanie. 
